\title{
Evolution of Philodendron (Araceae) species along Neotropical biomes
}

Leticia Loss-Oliveira, Cassia CMS Sakuragui, Maria de Lourdes Soares, Carlos G Schrago

Philodendron is the second most diverse genus of the Araceae, a tropical monocot family with significant morphological diversity along its wide geographic distribution in the Neotropics. Although evolutionary studies of Philodendron were conducted in recent years, the phylogenetic relationship among its species remains unclear. Additionally, analyses conducted to date suggested the inclusion of all American representatives of a closely related genus, Homalomena, within the Philodendron clade. A thorough evaluation of the phylogeny and timescale of these lineages is thus necessary to elucidate the tempo and mode of evolution of this large Neotropical genus and to unveil the biogeographic history of Philodendron evolution along the Amazonian and Atlantic Rain Forests, as well as open dry forests of South America. To this end, we have estimated the molecular phylogeny for 68 Philodendron species, which consists of the largest sampling assembled to date aiming the study of the evolutionary affinities. We have also performed ancestral reconstruction of species distribution along biomes. Finally, we contrasted these results with the inferred timescale of Philodendron and Homalomena lineage diversification. Our estimates indicate that American Homalomena is the sister clade to Philodendron. The early diversification of Philodendron took place in the Amazon Forest from Early to Middle Miocene, followed by colonization of the Atlantic Forest and the savanna-like landscapes, respectively. Based on the age of the last common ancestor of Philodendron, the species of this genus diversified by rapid radiations, leading to its wide extant distribution in the Neotropical region. 


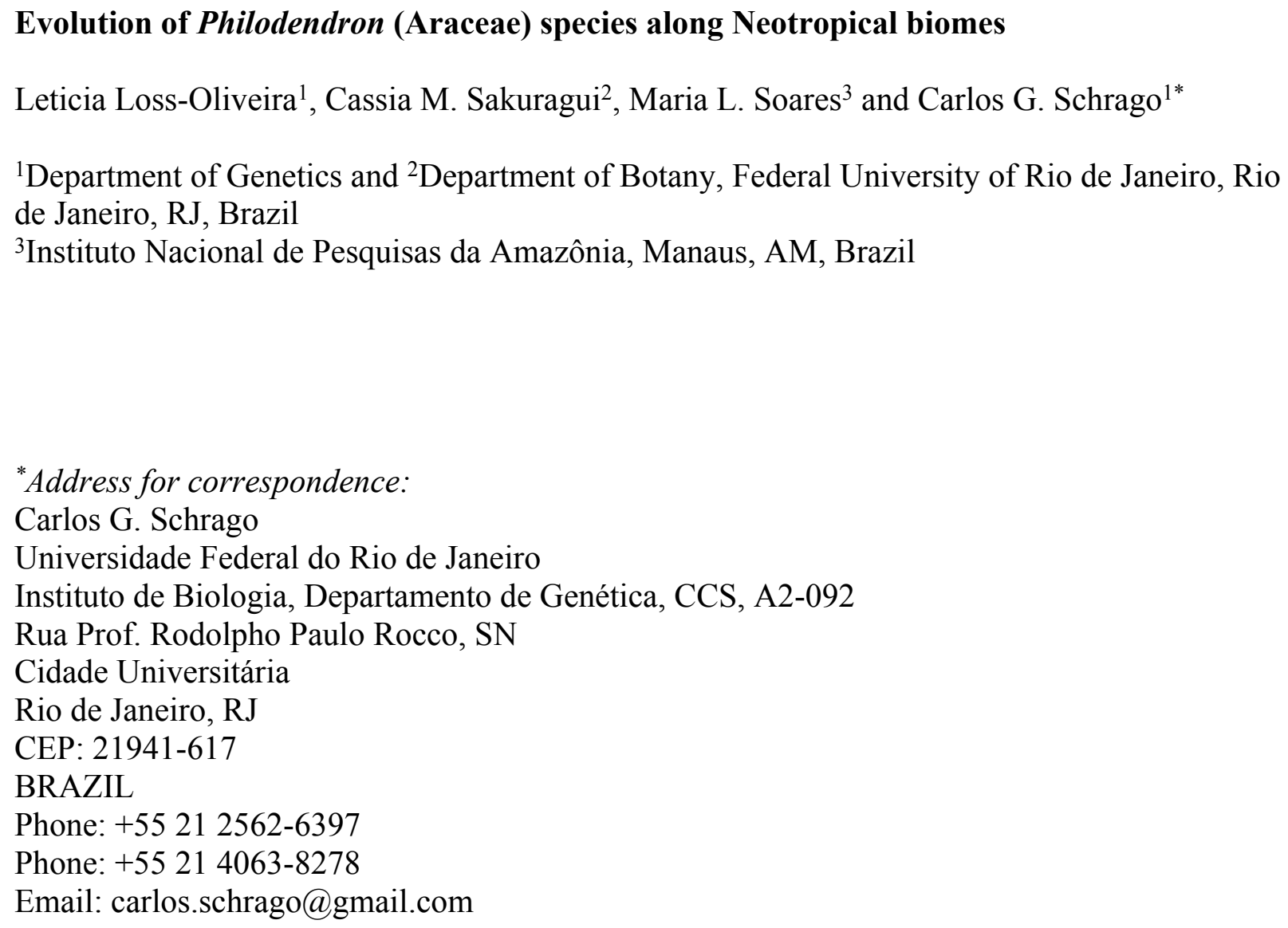

*Address for correspondence:

Carlos G. Schrago

Universidade Federal do Rio de Janeiro

Instituto de Biologia, Departamento de Genética, CCS, A2-092

Rua Prof. Rodolpho Paulo Rocco, SN

Cidade Universitária

Rio de Janeiro, RJ

CEP: 21941-617

BRAZIL

Phone: +55 $212562-6397$

Phone: +55 21 4063-8278

Email: carlos.schrago@gmail.com

Running title: Diversification of Philodendron

Keywords: biogeography; South America; Amazon; Andes; dispersal; supertree 
36 Abstract

37

Philodendron is the second most diverse genus of the Araceae, a tropical monocot family with significant morphological diversity along its wide geographic distribution in the Neotropics. Although evolutionary studies of Philodendron were conducted in recent years, the phylogenetic relationship among its species remains unclear. Additionally, analyses conducted to date suggested the inclusion of all American representatives of a closely related genus, Homalomena, within the Philodendron clade. A thorough evaluation of the phylogeny and timescale of these lineages is thus necessary to elucidate the tempo and mode of evolution of this large Neotropical genus and to unveil the biogeographic history of Philodendron evolution along the Amazonian and Atlantic Rain Forests, as well as open dry forests of South America. To this end, we have estimated the molecular phylogeny for 68 Philodendron species, which consists of the largest sampling assembled to date aiming the study of the evolutionary affinities. We have also performed ancestral reconstruction of species distribution along biomes. Finally, we contrasted these results with the inferred timescale of Philodendron and Homalomena lineage diversification. Our estimates indicate that American Homalomena is the sister clade to Philodendron. The early diversification of Philodendron took place in the Amazon Forest from Early to Middle Miocene, followed by colonization of the Atlantic Forest and the savanna-like

54 landscapes, respectively. Based on the age of the last common ancestor of Philodendron, the species of this genus diversified by rapid radiations, leading to its wide extant distribution in the Neotropical region. 


\section{Introduction}

59

60

61

62

63

64

65

66

67

68

70

71

72

73

74

75

76

77

78

79

80

Philodendron is an exclusively Neotropical genus, comprising 482 formally recognized species (Boyce \& Croat, 2013). Their geographic distribution range from Northern Mexico to Southern Uruguay (Mayo et al., 1997), consisting mainly of the biomes of the Amazonian and Atlantic Rain Forests and also the open dry forests of South America. According to Olson et al.'s (2001) classification of terrestrial biomes, South American open dry forests are composed of the Cerrado (savanna-like landscapes) and Caatinga biomes (Croat, 1997, Mayo, 1988, Mayo, 1989, Sakuragui et al., 2012a) (Figure 1). Philodendron species richness is especially significant in Brazil, where 168 species were described thus far (Sakuragui et al., 2012b).

Although Philodendron presents a significant morphological plasticity, wide leaf variation and several types of habits (Sakuragui et al., 2012b, Coelho, 2000), the inflorescence morphology of its representatives is largely conserved. The unisexual flowers in the spadix are clustered in male, female and sterile zones; located at the basal, median and superior portions, respectively (Figure $1 b$ ). The spadix, in nearly all of its extension, is surrounded by the spate (Sakuragui, 2001).

3 Currently, Philodendron species are grouped into three subgenera according to its floral and vegetative morphology and anatomy (Mayo, 1991, Mayo, 1988, Croat, 1997), namely, subgenus Meconostigma (Schott) Engl., which consists of 21 species (Gonçalves \& Salviani, 2002, Croat et al., 2002, Mayo, 1991); subgenus Pteromischum (Schott) Mayo, with 75 species (Coelho, 2000) and subgenus Philodendron (Mayo, 1986), comprising approximately 400 species (Coelho, 2000, Croat, 1997).

Because of the wide geographic range, patterns of distribution along niches, as well as the characteristic morphology, interest in investigating Philodendron systematics and evolution has 
81 increased in the last decades (Sakuragui et al., 2005, Mayo, 1986, Grayum, 1996, Croat, 1997).

82 Morphological and anatomical characters of flowers has been of special interest for phylogenetic

83 analysis due to their high level of variability (Sakuragui, 1998). However, the plasticity and

84 convergence of these characters in Philodendron may increase the probability of homoplasies

85 (Mayo, 1986, Mayo, 1989).

86 Recently, Gauthier et al. (2008) investigated the phylogenetic relationships of

87 Philodendron species based on three molecular markers, sampling a total of 49 species. This

88 work comprised the largest taxon sampling of the genus to date. In accordance to previous

89 analysis (Barabé et al., 2002, Mayo et al., 1997), authors questioned the monophyly of

90 Philodendron, suggesting the inclusion of all American species of the morphologically similar

91 genus, Homalomena Schott, within the Philodendron clade. Homalomena species occur in

92 America and Asia and its geographic distribution partly overlaps with Philodendron in the

93 Neotropics. The inference of the evolutionary relationships between Philodendron and

94 Homalomena has a significant biogeographic appeal. If American Homalomena species are

95 indeed more closely related to Philodendron than to Asian Homalomena, a single colonization

96 event should be considered. Unveiling the evolutionary relationships between those lineages is

97 thus necessary to elucidate their origin and subsequent diversification.

98 Besides phylogeny, several issues regarding Philodendron evolution remain unclear. For

99 example, the historical events that led to the wide geographic occurrence along biomes need a

100 thorough analysis. In this sense, investigating the evolutionary affinities of a large sample of

101 Philodendron species will shed light on how this lineage diversified along the Amazonian and

102 Atlantic Rain Forests, as well as South American open dry forests biomes, namely, the Cerrado

103 and Caatinga. To this end, we have performed an ancestral area reconstruction of Philodendron 
104 and Homalomena species and estimated the divergence times from a phylogeny inferred from the

105 largest Philodendron dataset composed to date. We were able to address the timing and pattern

106 of Philodendron diversification in selected Neotropical biomes with a focus on the evolutionary

107 relationships between the three Philodendron subgenera.

108

109 


\section{Materials and Methods}

111 Taxon and gene sampling

112 We have sequenced new data for 110 extant species of Philodendron and 16 species of

113 Homalomena of the following molecular markers: the nuclear $18 \mathrm{~S}$ and external transcribed

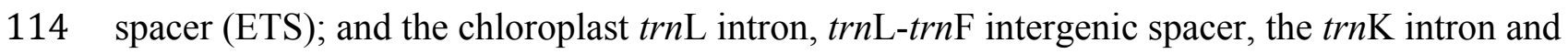

115 maturase $\mathrm{K}$ (matK) genes. Additionally, 13 outgroup species were analyzed, comprising the

116 genera Cercestis, Culcasia, Colocasia, Dieffenbachia, Heteropsis, Montrichardia, Nephthytis,

117 Furtadoa and Urospatha. Outgroup choice was based on the close evolutionary affinity of these

118 genera to Philodendron, as suggested by previous studies. The complete list of species included

119 in this study, the voucher and GenBank accession numbers were listed in Tables 1 and 2 of the

120 Supplementary Material.

121 Ancestral biome reconstruction is dependent on the estimated phylogeny and the

122 current geographic distribution of sampled species terminals. Thus, taxon sampling may impact

123 the inference of ancestral species distribution along biomes. As indicated in Table 1

124 (Supplementary Material), we have sampled all P. subg. Meconostigma species; 82 P. subg.

125 Philodendron species and 7 P. subg. Pteromischum species. Our sampling strategy is

126 representative of the current Philodendron diversity. Although $\sim 75 \%$ of the sampled species are

$127 P$. subg. Philodendron in our analysis, $\sim 82 \%$ of Philodendron species consist of $P$. subg.

128 Philodendron (Boyce \& Croat, 2013, Sakuragui et al., 2012a).

129

130 DNA isolation, amplification and sequencing

131 Genomic DNA was isolated with QIAGEN DNeasy Blood \& Tissue kit from silica-dried

132 or fresh leaves. Primers used for amplification and sequencing were listed in Table 3 of 
133 Supplementary Material. Sequencing reactions were performed in the Applied Biosystems

$1343730 x 1$ automatic sequencer and edited with the Geneious 5.5.3 software.

135 Alignment and phylogenetic analysis

136 Molecular markers were individually aligned in MAFFT 7 (Katoh \& Standley, 2013) and

137 then manually adjusted in SeaView 4 (Gouy et al., 2010). We estimated individual gene trees

138 (Fig. 1, SM) for each molecular marker in MrBayes 3.2.2 (Huelsenbeck \& Ronquist, 2001,

139 Ronquist \& Huelsenbeck, 2003) using the GTR + G substitution model. The Markov chain

140 Monte Carlo (MCMC) algorithm was ran twice for 10,000,000 generations, using four chains.

141 Chains were sampled every $100^{\text {th }}$ cycle and a burn-in of $20 \%$ was applied. A supertree was

142 estimated from the tree topologies of each molecular marker using the PhySIC_IST algorithm,

143 available at the ATGC-Montpellier online server (http://www.atgc-montpellier.fr/physic_ist/).

144 Only clades with posterior probability $\geq 85 \%$ were considered to estimate the supertree. We have

145 used this approach to avoid the impact of missing data in phylogeny estimation (Scornavacca et

146 al., 2008). As PhySIC_IST calculates non-plenary supertrees, it removes taxa with significant

147 topological conflict and/or with small taxon sampling (Scornavacca et al., 2008). The final

148 supertree was thus composed of 89 terminals, as 50 terminals were discarded due to conflicting

149 resolutions.

150 In order to assess the stability of the (Philodendron + American Homalomena) clade, we

151 have calculated the log-likelihoods of alternative topological arrangements in PhyML 3.0

152 (Guindon et al., 2009) using the species sampling of the supertree. We have tested the following

153 topologies: (I) (American Homalomena (P. subg. Philodendron + P. subg. Meconostigma); (II)

154 (P. subg. Meconostigma (P. subg. Philodendron + American Homalomena) and (III) (P. subg.

155 Philodendron (P. subg. Meconostigma + American Homalomena). The significance of the 
156 difference in log-likelihoods between topologies was tested with the approximately unbiased

157 (AU) and the Shimodaira-Hasegawa (SH) tests implemented in CONSEL 1.2.0 (Shimodaira \&

158 Hasegawa, 2001).

159 Divergence time inference

160 Dating Philodendron evolutionary history is difficult mainly because of the scarcity of

161 the fossil record (Loss-Oliveira et al., 2014). For instance, Dilcher and Daghlian (1977), based

162 on fossilized leaves, described a putative $P$. subg. Meconostigma fossil from the Eocene of

163 Tennessee (56.0 - 33.9 Ma). However, Mayo (1991) identified the referred fossil as a Peltranda.

164 Thus, we have decided not to use this fossil as calibration information. Alternatively, in order to

165 estimate divergence times, we have assigned a prior on the rate of nucleotide substitution. We

166 were then prompted to infer the evolutionary rates of plastid coding regions of monocots using a

167 large sample of publicly available chloroplast genomes. Nuclear genes were excluded from

168 dating analysis because of the absence of prior information on evolutionary rates.

169 To estimate monocots substitution rate, we used chloroplast genomes from 154 Liliopsida

170 species retrieved from the GenBank (Table 4). All orthologous coding regions were concatenated

171 into a single supermatrix. Maximum likelihood phylogentic reconstruction was implemented in

172 RaxML 7.0.3 (Stamatakis, 2006) under GTR model. Molecular dating of monocots (Liliopsida)

173 was conducted under a Bayesian framework, using fossil information obtained from Iles et al.

174 (Iles et al., 2015) (Table 5). Because the number of terminals used was large, rate estimation was

175 conducted with the MCMCTree program of PAML 4.8 package (Yang, 2007) using the

176 approximate likelihood calculation (dos Reis \& Yang, 2011) and the uncorrelated model of

177 evolution of rates. In MCMCTree, posterior distributions were obtained via MCMC; chains were

178 sampled every 500th cycle until 50,000 trees were collected. We performed two independent 
179 replicates to check for convergence of the estimates. Calibration information for Liliopsida was

180 entered as minimum and maximum bounds of uniform priors. The estimated mean substitution

181 rate was inferred at $3.26 \times 10^{-9}$ substitutions/site/year $(\mathrm{s} / \mathrm{s} / \mathrm{y})$. This value is significantly higher

182 than the previous estimate of Palmer (1991), which reported an average substitution rate of $0.7 \mathrm{x}$

$18310^{-9} \mathrm{~s} / \mathrm{s} / \mathrm{y}$ for angiosperm platids. As the credibility interval of our estimate was large, we

184 adopted a Gaussian prior for evolutionary rates with a 95\% highest probability density (HPD)

185 interval that included maximum and minimum values of our estimate and that of Palmer's.

186 Dating analysis of Philodendron and Homalomena species was performed in BEAST

187 using a relaxed molecular clock with evolutionary rates modeled by an uncorrelated lognormal

188 distribution; the GTR $+\mathrm{G} \square$ model of sequence was applied. MCMC algorithm was ran for

$18950,000,000$ generations and sampled every $1,000^{\text {th }}$ cycle, with a burn-in of $20 \%$.

190

191

192

193

194

195

196

197

198

199

200

201

\section{Biome shifts}

To unveil how Philodendron species colonized the Amazon forest, Atlantic Forest, Cerrado and Caatinga, we conducted a Bayesian Binary MCMC (BBM) (Yu et al., 2012, Ronquist \& Huelsenbeck, 2003) implemented in Reconstruct Ancestral State in Phylogenies 2.1b (RASP) software (Yu et al., 2012). The input tree topology was the supertree estimated in PhySIC_IST. BBM chains were ran for 10,000,000 generations and were sampled every $1000^{\text {th }}$ cycle. State frequencies were estimated under the F81 model with gamma rate variation. Information on the occurrence of each Philodendron species along Neotropical biomes was obtained from Sakuragui et al. (2012b) and from the (Team) CATE Araceae (http://araceae.emonocot.org). 


\section{Results}

204 The Homalomena genus was not recovered as monophyletic; the Asian Homalomena 205 clustered within a single group and the American representatives clustered independently, as 206 sister to Philodendron species (Figure 2). Although our analysis failed to support the monophyly 207 of Philodendron with significant statistical support, the topological arrangement in which 208 Philodendron is a monophyletic genus was significantly supported by the AU and SH tests ( $p<$ 209 0.05, Figure 3, Table 6SM). Within Philodendron, subg. Meconostigma was recovered as 210 monophyletic (Fig. 2, node D), whereas subg. Philodendron was recovered as polyphyletic (Fig.

211 2, node E). Finally, the monophyly of $P$. subg. Pteromischum was not inferred, because

212 Pteromischum species clustered with P. subg. Philodendron species.

213 We estimated that the last common ancestor (LCA) of Philodendron diversified in the 214 Amazon Forest (Fig. 4, node B) at ca. 8.6 Ma (6.8 - 12.1Ma) 95\% HPD. Thus, we inferred that 215 the LCA of Philodendon diversified from Middle to Late Miocene. This also suggests that the 216 divergence between Philodendron and the American Homalomena occurred in a short period of 217 time after this American lineage diverged from the Asian Homalomena (Figure 4, nodes B and 218 A, respectively).

The earliest events of Philodendron diversification occurred exclusively in the Amazon

220 Forest (e.g., Fig. 4, nodes C, D, E, F). The ancestors of Atlantic Forest lineages were inferred to 221 have been distributed in the Amazon (Fig. 4, nodes I, J and nodes G, H). This pattern of 222 Amazonian ancestry of Atlantic Forest lineages was also observed in some terminal branches.

223 For instance, from node $\mathrm{K}$ to $P$. loefgrenii and from node $\mathrm{L}$ to $P$. imbe.

224 On the other hand, the majority of Cerrado species evolved from Atlantic Forest

225 ancestors (Fig. 4, nodes $\mathrm{J}$ and $\mathrm{M}$; node $\mathrm{N}$ to $P$. rhizomatosum and $P$. pachyphyllum). In subgenus 
226 Meconostigma, the age of early species diversification into Atlantic Forest was dated at $3.7 \mathrm{Ma}$

227 (5.6 - 2.7 Ma) (Fig. 4, node J), whereas in the P. subg. Philodendron early lineage

228 diversification occurred at 4.1 Ma (5.5 - 3.0 Ma) (Fig. 4, node J). Therefore, during a period of

$2295.0-6.0 \mathrm{Ma}$, Philodendron species occupied exclusively the Amazon Forest. The diversification

230 into Cerrado biome occurred later, at approximately 1.7 Ma (3.3 - 1.1 Ma) (Fig. 4, node M).

231

232 


\section{Discussion}

234 Phylogenetic relationship between Philodendron and Homalomena

235 In this study, Asian Homalomena was recovered as sister to the (Philodendron +

236 American Homalomena) clade, and Furtadoa mixta clustered with the Asian Homalomena clade.

237 The evolutionary affinities of American Homalomena, P. subg. Meconostigma and P. subg.

238 Philodendron were not strongly supported. However, the topological arrangement in which

239 Philodendron is a monophyletic genus was statistically significant by the AU and SH tests,

240 suggesting the monophyly of Philodendron.

241 Previous studies have reported conflicting results concerning the monophyly of

242 Philodendron and the phylogenetic status of American Homalomena (Figure 5). For instance,

243 Barabé et al. (2002), based on the $\operatorname{trn} \mathrm{L}$ intron and the $\operatorname{trnL}-\operatorname{trnF}$ intergenic spacer, proposed $P$.

244 subg. Philodendron as a paraphyletic group and was unable to solve the (P. subg. Meconostigma

$245+$ Asian + American Homalomena) polytomy (Figure 5A). Gauthier et al. (2008) recovered the

246 American Homalomena as sister to Philodendron and the Asian Homalomena as sister to the

247 (American Homalomena + Philodendron) clade, although their Bayesian analysis inferred a

248 paraphyletic Philodendron, with $P$. subg. Pteromischum sister to the American Homalomena

249 (Figure 5B and 5C, respectively). Alternatively, Cusimano et al. (2011) recovered a

250 monophyletic Philodendron, with Homalomena as sister lineage of Furtadoa (Figure 5D).

251 Recently, Yeng et al. (2013) estimated the Homalomena phylogeny based on the nuclear ITS

252 marker and also sampled Philodendron species. In the ML and Bayesian trees reported in their

253 study, $P$. subg. Pteromischum was closely related to the American Homalomena, whereas $P$.

254 subg. Meconostigma and P. subg. Philodendron were recovered as sister taxa (Figure 5E). 
256 phylogenetic methods, markers and taxon sampling. Gauthier et al. (2008) was the only study

257 intended to investigate specifically the systematics of Philodendron genus. When compared to

258 their analysis, our study included a larger sampling of taxa and molecular markers with the aim

259 of estimating the phylogeny of Philodendron and Homalomena species; it is also the first

260 analysis that used a supertree approach to this end.

261 Our phylogeny characteristically presents short branch lengths within the Philodendron

262 clade. The high frequency of polytomies indicates the genetic similarity among terminals, which

263 is further corroborated by the ease in obtaining artificial hybrids between different species. This

264 corroborates a scenario of low genetic differentiation and low reproductive isolation (Carlsen,

265 2011).

266

Philodendron diversification may also consist of several recent rapid radiation events.

267 Phylogenetic reconstruction under this scenario is challenging, because of a significant amount

268 of substitutions is needed to accumulate within short periods of time (Maddison and Knowles,

269 2006). However, morphological variation of Philodendron is remarkable, which seems

270 contradictory considering the previously discussed features. However, it has been extensively

271 discussed that morphological variation is not a suitable proxy for genetic variation (e.g.,

272 Prud'Homme et al., 2011; Houle et al., 2010). Many environmental and epigenetic factors may

273 can increase phenotypic variation even in the absence of DNA sequence variation (Prud'Homme

274 et al., 2011). Evidently, we cannot rule out the possibility that DNA regions that present

275 significant genetic differences between species were not sampled in this work.

276 Diversification of Philodendron and Homalomena 
Although the chronology of Philodendron divergence was not extensively focused by

278 previous studies, Nauheimer et al. (2012) analyzed the global history of the entire Araceae

279 family based on a supermatrix composed of 5 chloroplast markers and several well-established

280 calibration points. Their analysis included a single Philodendron species and estimated age of the

281 Philodendron/Asian Homalomena divergence at approximately $20.0 \mathrm{Ma}$ (ranging from $31.0-$

$2829.0 \mathrm{Ma}$ ). This study, however, also included a single species of Asian Homalomena.

283 The wide range of the posterior distribution credibility intervals of Nauheimer et al.

284 (2012) hampers the proposition of putative biogeographic scenarios for the evolution of

285 Philodendron, American and Asian Homalomena. Differences between their timescale and the

286 divergence times proposed in this study might therefore be due to methodological differences

287 caused by their reduced taxonomic sampling. Nevertheless, both our estimate of the age of the

288 Philodendron divergence from Asian Homalomena and that of Nauheimer et al. (2012) suggests

289 that this event took place when South America was essentially an isolated continent.

290 The isolation of the South American continent persisted from approximately 130.0 Ma

291 (Smith \& Klicka, 2010) to $3.5 \mathrm{Ma}$ (Vilela et al., 2014), with the rise of the Panamanian land

292 bridge. Therefore, from the Early to Middle Miocene there was no land connection with North

293 America, Asia or Africa (Oliveira et al., 2010). If dispersal, rather then vicariance, is the most

294 plausible hypothesis to explain Philodendron and American Homalomena colonization of the

295 Neotropics, hypotheses on the possible routes of colonization should be investigated. Based on

296 the continental arrangement during the Miocene, we propose that the dispersal of Philodendron

297 and American Homalomena ancestor could have followed four possible routes (Figure 6): (1)

298 from Asia to North America through the Bering Strait; (2) from Africa to the Neotropics by 
299 crossing the Atlantic ocean; (3) from Asia to Neotropics by crossing Pacific ocean; and (4) from

300 Asia to Neotropics, also by crossing the Atlantic ocean.

Kingdom, Venezuela, Yemen, Colombia and Canada (Shufeldt, 1917, Berry, 1936, Bogner et al., 2005, Chandler, 1964, Dorofeev, 1963, As-Saruri et al., 1999, Wilde \& Frankenhauser, 1998, 2005, Wing et al., 2009, Stockey et al., 2007). However, as none of the fossil specimens was described as closely related to Philodendron or Homalomena, the Araceae fossil record fails to corroborate any dispersal hypothesis in particular. oceanic dispersal through ca. 2,000 km - the minimum distance between Africa and the Neotropics (Oliveira et al., 2010) - through Atlantic paleocurrents, which were probably stronger than Pacific currents. This hypothesis is congruent with the clustering of Philodendron and American Homalomena into a single clade, assuming Africa as the center of diversification of

314 Asian and American Homalomena, as well as Philodendron. However, we should conisder that the last recent common ancestor of Philodendron and Homalomena was distributed in Africa. On

316 the other hand, this hypothesis is corroborated by the distribution of the extant Philodendron and Homalomena species. Givnish and colleagues (2004) also suggested two long distance dispersal events through the Atlantic, but in the opposite direction. Their analysis indicated that

319 Bromeliaceae and Rapateaceae arose in the Guayana Shield of northern South America and reached 320 tropical west Africa via long-distance dispersal at ca. 6-8 Ma. 
323 saline conditions for long periods of time (Lo et al., 2014). Although such features have not been

324 evualuated for Philodendron and Homalomena, some Homalomena species inhabits swamp

325 forests and open swamps. Thus, features that would favor their survival in waterlogged

326 environments could also influence their maintenance in seawater.

Although route 3 is geographically unlikely due to the $8,000 \mathrm{~km}$ distance between Asia

328 and the Neotropics through the Pacific Ocean (Oliveira et al., 2010), it cannot be completely

329 discarded, because it is corroborated by the extant distribution of Homalomena and

330 Philodendron. Finally, route 4 suggests the dispersal through the Atlantic ocean from Asia to the

331 Neotropics. This is also an improbable hypothesis, because the African continent would act as a

332 barrier between Asia and the Neotropics, requiring the dispersal through both the Indian and the

333 Atlantic oceans.

334 The extant distribution of Philodendron and Homalomena species and the scarcity of

335 fossil information challenge the proposition of a scenario for the origin of Philodendron and

336 American Homalomena in the Neotropics. However, the biological and geographical information

337 provided to date indicates a long distance oceanic dispersal through the Atlantic, as suggested by

338 route 2, as the most plausible hypothesis to explain Philodendron and American Homalomena

339 colonization of the Neotropics.

340 Early diversification of Philodendron species

341 According to our analysis, the last common ancestor of Philodendron and the American

342 Homalomena was distributed in the Amazon Forest about 8.6 Ma (11.1 - 6.8 Ma) during the

343 Middle/Late Miocene. Interestingly, this time estimate is very close to the age of the divergence

344 between the (Philodendron/American Homalomena) clade from the Asian Homalomena (Fig. 4,

345 node A). The Middle and Late Miocene were characterized by wetland expansion into western 
346 Central Amazonia, which fragmented the rainforest and formed extensive wetlands (Jaramillo et

347 al., 2010). According to our analysis, Philodendron earliest divergence events took place in this

348 scenario. The Amazon forest, from the Late Miocene to the beginning of Pliocene, was

349 composed of a diverse and well-structured forest. The Amazon river landscape was well

350 established, this probably allowed the extensive development of the Amazonian terra firme

351 forest (Jaramillo et al., 2010). This scenario is compatible with the biology of extant species of

352 Philodendron, because a well-structured forest would allow the development of epiphyte and

353 hemiepiphyte species, such as Philodendron.

354 Philodendron diversification along Neotropical biomes

355 Our results suggest that Philodendron species occurred exclusively at the Amazon forest

356 for ca. 5.0 - 6.0 Ma. During the Pliocene, as result of the glacial cycles, climate cooling and

357 drying permitted the expansion of the open savanna areas, mostly represented by the 'dry

358 diagonal', which is constituted by the Caatinga, Cerrado and Chaco biomes. This consisted of a

359 crucial event, because it resulted in the isolation of the Atlantic forest in the east coast of South

360 America (DaSilva \& Pinto-da-Rocha, 2013), which is synchronous to the inferred age of the

361 early diversification of Philodendron in this biome. This also corroborates the hypothesis that the

362 Atlantic forest taxa present a closer biogeographic relationship with the Amazon forest, as

363 proposed by Amorim and Pires (1996) and Eberhard and Bermingham (2005). After the

364 separation between Atlantic and Amazon Forests during the Pliocene, species dispersal might

365 have been common through the forest patches (DaSilva and Pinto-da-Rocha, 2013).

366 Roig-Juñent and Coscarón (2001) and Porzecanski and Cracraft (2005) suggested that the

367 Atlantic rainforest also presents similarities in organismal composition with the Cerrado biome.

368 This association would have been a result of dispersal events through gallery forests. The history 
369 of the formation of Cerrado biome is still uncertain (Zanella, 2013, Werneck, 2011), but our

370 analysis indicated that the ancestors of Philodendron clades from the Cerrado were distributed in

371 the Atlantic forest. Therefore, we also corroborate the hypothesis of lineage dispersal from the

372 Atlantic Forest to the Cerrado biome. These events would have occurred after the colonization

373 the Atlantic Forest by Philodendron species.

374

375 Final considerations on Philodendron evolution

376 Given the significant morphological diversity of Philodendron, its widespread

377 distribution in the Neotropics and the age of the Araceae family ( 140.0 Ma, Nauheimer et al., 378 2012), it would be expected that the origin of this genus was older. In sharp contrast, we have

379 estimated phylogenies with very short branch lengths and very recent divergence times. A 380 similar scenario was reported by Carlsen and Croat (2013) for Anthurium, which is the most

381 diverse Araceae genus, and also by Nagalingum and colleagues (2011) for cycads. Therefore, the 382 inferred tempo and mode of evolution of Philodendron species were reported in several plant 383 families.

384

385 Conclusion

386 The present work was the first attempt to establish a chronological background for the 387 diversification of this highly diverse genus and to suggest possible routes of colonization of the 388 ancestors of Neotropical Philodendron and Homalomena. Philodendron was statistically 389 supported as a monophyletic genus, sister to American Homalomena by AU and SH tests. The 390 last common ancestor of Philodendon diversified from the Middle to the Late Miocene in the 391 Amazon Forest, where the earliest events of Philodendron diversification occurred. Amazon was 
392 also the exclusive biome occupied by Philodendron species during a 5.0 - 6.0 million years

393 period. Atlantic Forest lineages of $P$. subg. Meconostigma and $P$. subg. Philodendron diverged

394 from Amazonian ancestors. On the other hand, the majority of Cerrado species evolved from

395 Atlantic Forest ancestors, from the Late Miocene to the Pliocene.

396 


\section{Acknowledgements}

398 We thank Petrobrás and INPA for allowing field expeditions in their biological reserves. We also

thank Alexandre Antonelli for valuable contributions in the manuscript text.

400

401

402

403

404

405

406

407

408

409

410

411

412

413

414

415

416

417

418

419

420

421

422

423

424

425

426

427

428

429

430

431

432

433

434

435

436

437

438

439

\section{References}

Amorim, D. S. \& Pires, M. R. S. (1996) Neotropical biogeography and a method for maximum biodiversity estimation. (Bicudo, C. E. M. \& Menezes, N. A., eds.). pp. 183-219. CNPq, Campos do Jordão.

As-Saruri, M. L., Whybrow, P. J. \& Collinson, M. E. 1999. Geology, fruits, seeds, and vertebrates (Sirenia) from the Kaninah Formation (Middle Eocene), Republic of Yemen. Fossil Vertebrates of Arabia: 443-453

Barabé, D., Bruneau, a., Forest, F. \& Lacroix, C. 2002. The correlation between development of atypical bisexual flowers and phylogeny in the Aroideae (Araceae). Plant Systematics and Evolution 232: 1-19.

Berry, E. W. 1936. Tertiary plants from Venezuela. Proceedings of the United States National Museum 83: 335-360.

Bogner, J., Hoffman, G. L. \& Aulenback, K. R. 2005. A fossilized aroid infructescence, Albertarum pueri geno. nov. et sp. nov., of Late Cretaceous (late Campanian) age from the Horseshoe Canyon Formation of southern Alberta, Canada. Canadian Journal of Earth Sciences 85: 591-598.

Boyce, P. \& Croat, T. (2013) The Überlist of Araceae: Totals for published and estimated number of species in aroid genera. pp. 7-9.

Butzin, M., Lohmann, I. G. \& Bickertl, T. 2011. Miocene ocean circulation inferred from marine carbon cycle modeling combined with benthic isotope records. Paleoceanography 26.

Carlsen, M. (2011) Understanding the origin and rapid diversification of the genus Anthurium Schott (Araceae), integrating molecular phylogenetics, morphology and fossils. Vol. Ph.D. pp. 159. University of Missouri, USA.

Carlsen, M. M. \& Croat, T. B. 2013. A Molecular Phylogeny of the Species-Rich Neotropical Genus $<\mathrm{I}>$ Anthurium $</ \mathrm{I}>$ (Araceae) based on Combined Chloroplast and Nuclear DNA. Systematic Botany 38: 576-588.

Chandler, M. E. J. (1964) The Lower Tertiary Floras of Southern England. In: A summary and survey of findings in the light of recent botanical observations, Vol. 4. pp. British Museum (Natural History), London.

Coelho, M. A. N. 2000. Philodendron Schott (Araceae): morfologia e taxonomia das espécies da Reserva Ecológica de Macaé de Cima - Nova Friburgo, Rio de Janeiro, Brasil. Rodriguesia 51: 21-68.

Cohen, K.M., Finney, P.L., Gibbard, P.L. \& Fan, J.-X. 2015. The ICS International Chronostratigraphic Chart. Episodes 36 (3).

Croat, T. B. 1997. A revision of Philodendron subgenus Philodendron (Araceae) for Mexico and Central America. Annals of the Missouri Botanical Garden 84: 311-704.

Croat, T. B., Mayo, S. J. \& Boss, J. 2002. A new species of Brazilian Philodendron subgenus Meconostigma (Araceae). Aroideana 25: 63-66. 
440 Cusimano, N., Bogner, J., Mayo, S. J., Boyce, P. C., Wong, S. Y., Hesse, M., Hetterscheid, W.

441

442

443

444

445

446

447

448

449

450

451

452

453

454

455

456

457

458

459

460

461

462

463

464

465

466

467

468

469

470

471

472

473

474

475

476

477

478

479

480

481

482

483

484

485

L. a., Keating, R. C. \& French, J. C. 2011. Relationships within the Araceae: Comparison of morphological patterns with molecular phylogenies. American Journal of Botany 98: 654-668.

DaSilva, M. \& Pinto-da-Rocha, R. (2013) História biogeográfica da Mata Atlântica: Opiliões (Arachnida) como modelo para sua inferência. In: Biogeografia da América do SulPadrões e Processos, (Carvalho, C. J. B. \& Almeida, E. A. B., eds.). pp. 306. Roca.

Dilcher, D. L. \& Daghlian, C. P. 1977. Investigations of Angiosperms from the Eocene of Southeastern North America: Philodendron Leaf Remains. American Journal of Botany 64: 526-526.

Dorofeev, P. I. 1963. Tretichnye Flory Zapadnoi Sibiri (Tertiary Floras of Western Siberia). Moskva, Izd-vo Akademii nauk SSSR.

dos Reis, M. \& Yang, Z. H. 2011. Approximate Likelihood Calculation on a Phylogeny for Bayesian Estimation of Divergence Times. Molecular Biology and Evolution 28: 21612172.

Eberhard, J. R. \& Bermingham, E. 2005. Phylogeny and comparative biogeography of Pionopsitta parrots and Pteroglossus toucans. Molecular Phylogenetics and Evolution 36: 288-304.

Gauthier, M.-p. L., Barabe, D. \& Bruneau, A. 2008. Molecular phylogeny of the genus $<\mathrm{i}>$ Philodendron $</ \mathrm{i}>$ (Araceae): delimitation and infrageneric classification. Botanical Journal of the Linnean Society 156: 13-27.

Givnish, T.J., Millam, K.C., Evans, T.M. J.C., Hall, J.C., Pires , Berry, P.E. \& Sytsma K.J. 2004. Ancient vicariance or recent long-distance dispersal? Inferences about phylogeny and South American-African disjunction in Rapateaceae and Bromeliaceae based on ndhf sequence data. International Journal of Plant Sciences 165: 35-54.

Gonçalves, E. G. \& Salviani, E. R. 2002. New species and changing concepts of Philodendron subgenus Meconostigma (Araceae). Aroideana 25: 2-15.

Gouy, M., Guindon, S. \& Gascuel, O. 2010. SeaView version 4: A multiplatform graphical user interface for sequence alignment and phylogenetic tree building. Mol Biol Evol 27: 221-4.

Grayum, M. H. 1996. Revision of Philodenron Subgenus Pteromischum (Araceae) for Pacific and Caribean Tropical America. Systematic Botany Monographs 47: 234.

Guindon, S., Delsuc, F., Dufayard, J. F. \& Gascuel, O. 2009. Estimating maximum likelihood phylogenies with PhyML. Methods Mol Biol 537: 113-37.

Houle, D., Govindaraju, D.R. \& Omholt, S. 2010. Phenomics: the next challenge. Nature Reviews Genetics 11: 855-866.

Huelsenbeck, J. P. \& Ronquist, F. 2001. MRBAYES: Bayesian inference of phylogenetic trees. Bioinformatics (Oxford, England) 17: 754-755.

Iles, W. J. D., Smith, S. Y., Gandolfo, M. A. \& Graham, S. W. 2015. Monocot fossils suitable for molecular dating analyse. Botanical Journal of the Linnean Society.

Jaramillo, C., Hoorn, C., Silva, S. A. F., Leite, F., Herrera, F., Quiroz, L., Dino, R. \& Antonioli, L. (2010) The origin of the modern Amazon rainforest: implications of the palynological and palaeobotanical record. (Hoorn, C. \& Wesselingh, F., eds.). pp. 457-457. WileyBlackwell.

Katoh, K. \& Standley, D. M. 2013. MAFFT multiple sequence alignment software version 7: Improvements in performance and usability. Molecular Biology and Evolution 30: 772780 . 
486

487

488

489

490

491

492

493

494

495

496

497

498

499

500

501

502

503

504

505

506

507

508

509

510

511

512

513

514

515

516

517

518

519

520

521

522

523

524

525

526

527

528

529

530

Lo, E.Y.Y., Norman, C.D. \& Sun, M. 2014. Phylogeographic pattern of Rhizophora (Rhizophoraceae) reveals the importance of both vicariance and long-distance oceanic dispersal to modern mangrove distribution. BMC Evolutionary Biology 14:83.

Loss-Oliveira, L., Calazans, L. S., de Morais, E., Mayo, S. J., Schrago, C. G. \& Sakuragui, C. M. 2014. Floral evolution of Philodendron subgenus Meconostigma (Araceae). PLoS One 9: e89701.

Maddison, W.P. \& Knowles, L.L. 2006. Inferring phylogeny despite incomplete lineage sorting. Systematic Biology 55(1): 21-30.

Mayo, S. J. (1986) Systematics of Philodendron Schott (Araceae) with special reference to inflorescence characters. Vol. Ph.D. pp. 673. University of Keating, UK.

Mayo, S. J. 1988. Aspectos da evolução e da geografia do gênero Philodendron Schott (Araceae). Acta Botanica Brasilica 1: 27-40.

Mayo, S. J. 1989. Observations of gynoecial structure in Philodendron (Araceae). Botanical Journal of the Linnean Society 100: 139-172.

Mayo, S. J. 1991. A revision of Philodendron subgenus Meconostigma (Araceae). Kew Bulletin 46: 601-681.

Mayo, S. J., Bogner, J. \& Boyce, P. 1997. The genera of Araceae, 1 ed. Royal Botanical Garden, Kew.

Nagalingum, N.S., Marshall, C.R., Quental, T.B., Rai, H.S., Little, D.P. \& Mathews, S. 2011. Recent synchronous radiation of a living fossil. Science 334: 796-799.

Nauheimer, L., Metzler, D. \& Renner, S. S. 2012. Global history of the ancient monocot family Araceae inferred with models accounting for past continental positions and previous ranges based on fossils. New Phytologist 195: 938-950.

Oliveira, F. B., Molina, E. C. \& Marroig, G. (2010) South american primates, developments in Primatology: progress and prospects. pp. 547-547. Springer Science, Chicago.

Olson, D. M., Dinerstein, E., Wikramanayake, E. D., Burgess , N. D., Powell, G. N., Underwood, E. C., D'amico, J. A., Itoua, I., Strand, H. E., Morrison, J. C., Loucks, C. J., Allnutt, T. J., Ricketts, T. H., Kura, Y., Lamoreux, J. F., Wettengel, W. W., Hedao, P. \& Kassem, K. R. 2001. Terrestrial Ecoregions of the World A New Map of Life on Earth. Bioscience 51.

Opitz, W. 2005. Classification, natural history, and evolution of the genus Aphelocerus Kirsch (Coleoptera : Cleridae : Clerinae) - Abstracts. Bulletin of the American Museum of Natural History: 6-128.

Porzecanski, A. L. \& Cracraft, J. 2005. Cladistic analysis of distributions and endemism (CADE): Using raw distributions of birds to unravel the biogeography of the South American aridlands. Journal of Biogeography 32: 261-275.

Prud'Homme, B., Minervino, C., Hocine, M. Cande, J.D., Aouane, A., Dufour, H.D., Kassner, V.A. \& Gompel, N. 2011. Body plan innovation in treehoppers through the evolution of an extra wing-like appendage. Nature 473: 83-86.

Roig-Juñent, S. \& Coscarón, S. 2001. Biogeographical history of the Neotropical and Neoantarctic. Revista del Museo Argentino de Ciencias Naturales 3: 119-134.

Ronquist, F. \& Huelsenbeck, J. P. 2003. MrBayes 3: Bayesian phylogenetic inference under mixed models. Bioinformatics 19: 1572-4.

Sakuragui, C. M. (1998) Taxonomia e filogenia das espécies de Philodendron seção Calostigma (Schott) Pfeiffer no Brasil. pp. 238-238. 
531 Sakuragui, C. M. 2001. Biogeografia de Philodendron seção Calostigma ( Schott ) Pfeiffer (

532

533

534

535

536

537

538

539

540

541

542

543

544

545

546

547

548

549

550

551

552

553

554

555

556

557

558

559

560

561

562

563

564

565

566

567

568

569

570

571

572

573

574

575

576 Araceae ) no Brasil. Acta Scientiarum: 561-569.

Sakuragui, C. M., Calazans, L. S. B. \& Soares, M. L. (2012a) Philodendron Schott In: List of species of flora of Brazil. pp.

Sakuragui, C. M., Calazans, L. S. B. \& Soares, M. L. (2012b) Philodendron Schott In: List of species of flora of Brazil. Vol. 2014. pp. Botanical Garden of Rio de Janeiro.

Sakuragui, C. M., Mayo, S. J. \& Zappi, D. 2005. Taxonomic revision of Brazilian species of Philodendron Section Macrobelium. Kew Bulletin 60: 465-513.

Scornavacca, C., Berry, V., Lefort, V., Douzery, E. J. \& Ranwez, V. 2008. PhySIC_IST: cleaning source trees to infer more informative supertrees. Bmc Bioinformatics 9: 413.

Shimodaira, H. \& Hasegawa, M. 2001. CONSEL: for assessing the confidence of phylogenetic tree selection. Bioinformatics 17: 1246-7.

Shufeldt, W. D. 1917. Fossil birds found at Vero, Florida. Florida State Geological Survey Annual Report 9: 35-42.

Smith, B. T. \& Klicka, J. 2010. The profound influence of the Late Pliocene Panamanian uplift on the exchange, diversification, and distribution of New World birds. Ecography 33: 333-342.

Stamatakis, A. 2006. RAxML-VI-HPC: maximum likelihood-based phylogenetic analyses with thousands of taxa and mixed models. Bioinformatics 22: 2688-90.

Stockey, R. A., Rothwell, G. W. \& Johnson, K. R. 2007. Cobbania corrugata gen. et comb. nov. (Araceae): a floating aquatic monocot from the Upper Cretaceous of western North America. American Journal of Botany 94: 609-624.

Team, E. CATE Araceae. pp.

Vilela, J. F., Mello, B., Voloch, C. M. \& Schrago, C. G. 2014. Sigmodontine rodents diversified in South America prior to the complete rise of the Panamanian Isthmus. Journal of Zoological Systematics and Evolutionary Research 52: 249-256.

Werneck, F. P. 2011. The diversification of eastern South American open vegetation biomes: Historical biogeography and perspectives. Quaternary Science Reviews 30: 1630-1648.

Wilde, V. \& Frankenhauser, H. 1998. The Middle Eocene plant taphocoenosis from Eckfeld (Eifel, Germany). Review of Palaeobotany and Palynology 101: 7-28.

Wing, S. L., Herrera, F., Jaramillo, C. A., Gómez-Navarro, C., Wilf, P. \& Labandeira, C. C. 2009. Late Paleocene fossils from the Cerrejón Formation, Columbia, are the earliest record of Neotropical rainforest. Proceedings of the National Academy of Sciences 106: 18627-18632.

Yang, Z. H. 2007. PAML 4: Phylogenetic analysis by maximum likelihood. Molecular Biology and Evolution 24: 1586-1591.

Yeng, W. S., Jean, T. P., Kiaw, N. K., Othman, A. S., Boon, L. H., Ahmad, F. B. \& Boyce, P. C. 2013. Phylogeny of Asian Homalomena (Araceae ) Based on the ITS Region Combined with Morphological and Chemical Data Phylogeny of Asian Homalomena ( Araceae ) based on the ITS Region Combined with Morphological and Chemical Data. 38: 589599.

Yu, Y., Harris, A. J. \& He, X. J. (2012) RASP (Reconstruct Ancestral State in Phylogenies) 2.1b. $\mathrm{pp}$.

Zanella, F. C. (2013) Evolução da biota da Diagonal de Formações Abertas Secas da América do Sul. (Carvalho, C. J. B. \& Almeida, E. A. B., eds.). pp. 306-306. Roca, São Paulo. 


\section{$577 \quad$ Figure legends}

578 Figure 1A. Geographic distribution of Philodendron species along the Neotropical biomes of

579 Amazon, Atlantic Forest, Cerrado and Caatinga. B. Philodendron inflorescence and the flower 580 zones.

581 Figure 2. Supertree of Philodendron and Homalomena species.

582 Figure 3. Phylogeny of Philodendron and Homalomena corroborated by the approximately 583 unbiased (AU) test.

584 Figure 4. Ancestral biome reconstructions and divergence time estimates of Philodendron and 585 Homalomena lineages. The epoch intervals followed the international chronostatigraphic chart 586 (Cohen et al., 2015) and are indicated by dashed lines.

587 Figure 5. Phylogenetic relationships between Philodendron and Homalomena recovered by 588 previous studies. A. Barabé et al. (2002); B. Gauthier et al. (2008) using the maximum 589 parsimony method; C. Gauthier et al. (2008) using Bayesian analysis; D. Cusimano et al. (2011); 590 E. Yeng et al. (2013).

591 Figure 6. Putative dispersal routes of the ancestor of Philodendron and American Homalomena 592 to the Neotropical region during the Miocene.

593

594

595

596

597

598 


\section{Figure 1 (on next page)}

Figure 1

A. Geographic distribution of Philodendron species along the Neotropical biomes of Amazon, Atlantic Forest, Cerrado and Caatinga. B. Philodendron inflorescence and the flower zones. 
Amazon Forest Atlantic Forest

Caatinga

Cerrado

Male sterile zone

Female zone 


\section{Figure 2 (on next page)}

Figure 2

Supertree of Philodendron and Homalomena species. 


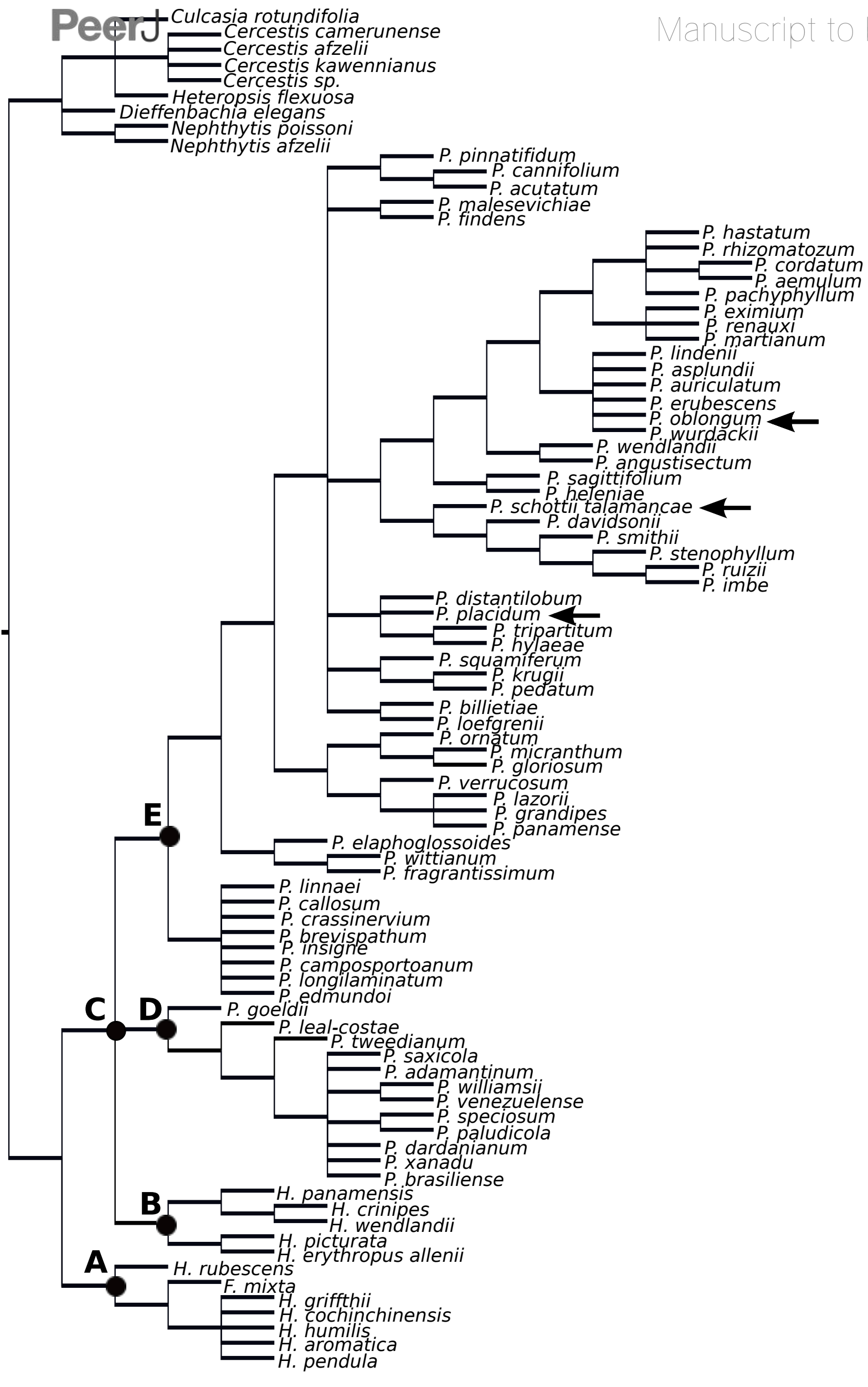

0.002 


\section{Figure 3 (on next page)}

Figure 3

Phylogeny of Philodendron and Homalomena corroborated by the approximately unbiased (AU) test. 
P. subg. Meconostigma

P. subg. Philodendron + Pteromischum

American Homalomena

Asian Homalomena 


\section{Figure 4 (on next page)}

Figure 4

Ancestral biome reconstructions and divergence time estimates of Philodendron and Homalomena lineages. The epoch intervals followed the international chronostatigraphic chart (Cohen et al., 2015) and are indicated by dashed lines. 


\section{Figure 5 (on next page)}

\section{Figure 5}

Phylogenetic relationships between Philodendron and Homalomena recovered by previous studies. A. Barabé et al. (2002); B. Gauthier et al. (2008) using the maximum parsimony method; C. Gauthier et al. (2008) using Bayesian analysis; D. Cusimano et al. (2011); E. Yeng et al. (2013). 

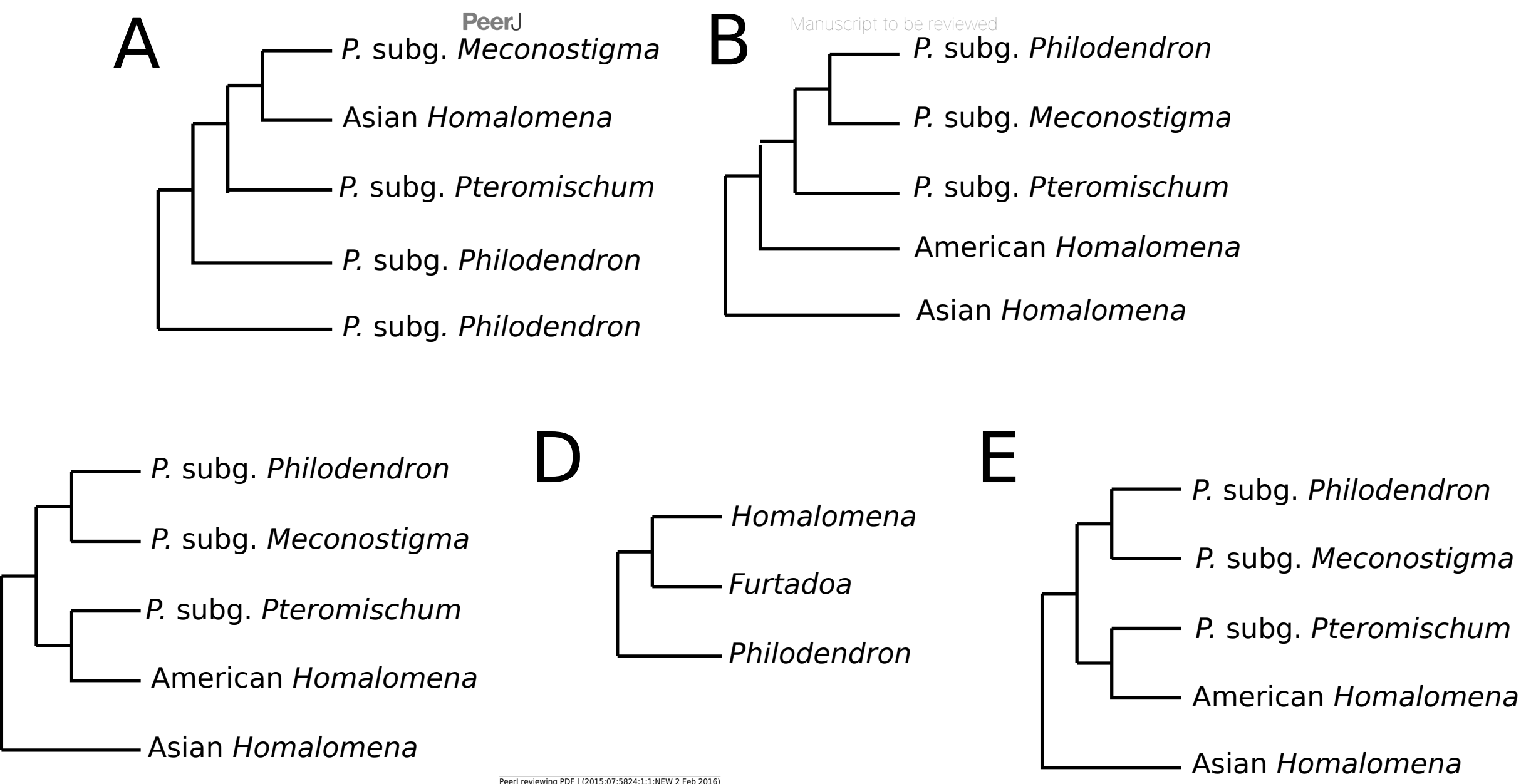


\section{Figure 6 (on next page)}

Figure 6

Putative dispersal routes of the ancestor of Philodendron and American Homalomena to the Neotropical region during the Miocene. 


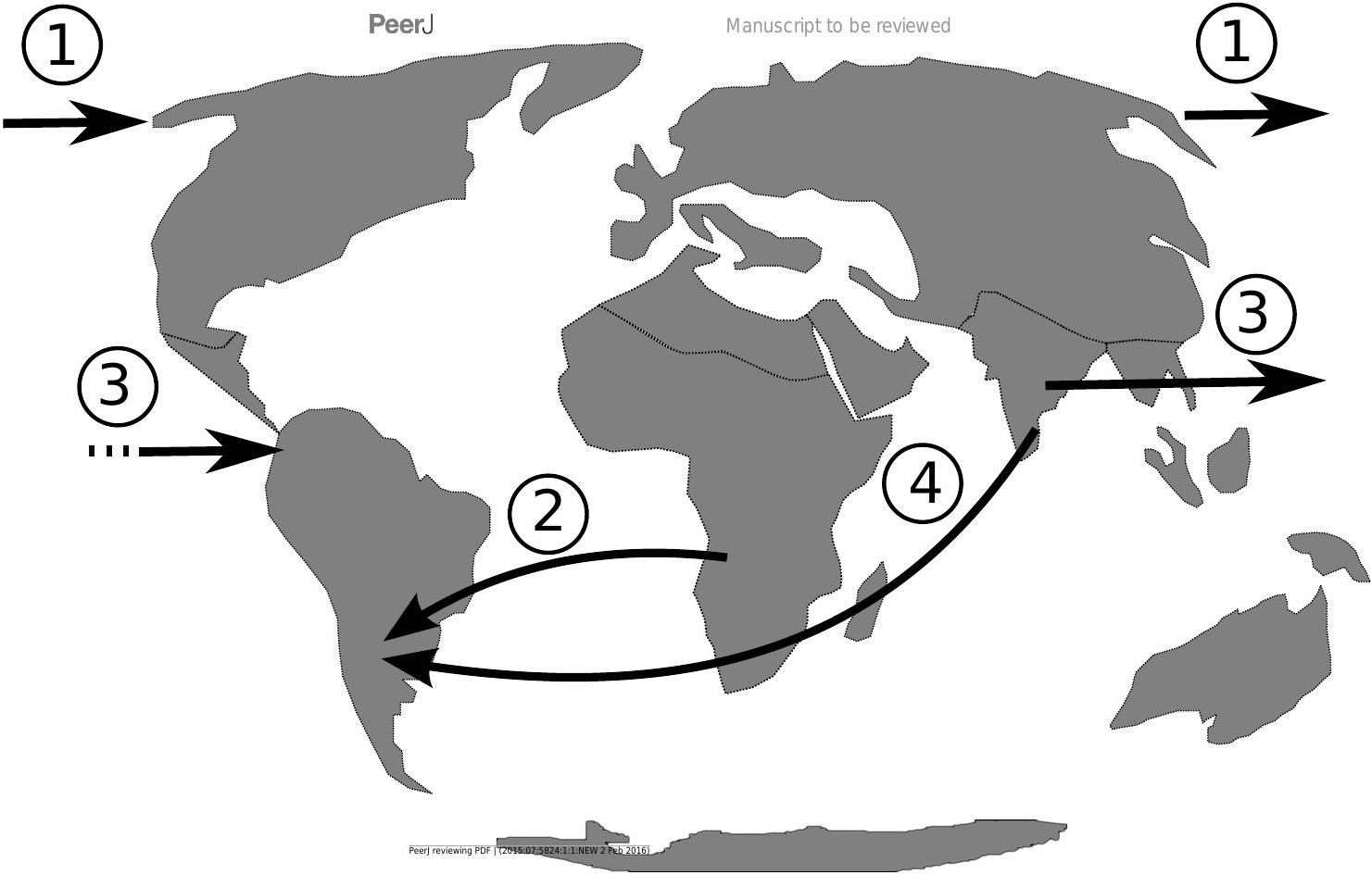

